\author{
METIN BAĞRIAÇIK (Ghent University, Belgium) and ANGELA RALLI \\ (University of Patras, Greece)
}

(Please refer to the print version before citing in STUF-Language Typology and Universals (68(3):323-357)

\title{
Phrasal vs. Morphological Compounds: Insights from Modern Greek and Turkish ${ }^{1}$
}

\begin{abstract}
In this paper, we compare Modern Greek nominal compounds to their Turkish counterparts and reveal that Modern Greek nominal compounds under investigation are morphological while Turkish ones are syntactically built. Based on this, we offer an explanation for the availability of phrasal compounds in Turkish but not in Modern Greek: phrase-level items can be involved in syntactic compounds, but not in morphological compounds involving solely morphological items. The study reveals that the locus of compound formation is not confined to a single module both cross-linguistically and within a language, but the locus of a specific type of compound in a language entails whether or not phrasal compounds with the same compound structure can also occur in that specific language.
\end{abstract}

\section{Introduction}

A compound is a "lexical unit made up of two or more elements, each of which can function as a lexeme independent of the other(s) in other contexts" (Bauer 2001: 695). According to this definition, prototypically, compounding (like other lexeme-formation operations) produces new lexemes, but questions arise with respect to the input of the process, and these questions are reflected in the conflicting views on the locus of compounding. An often observed similarity to syntactic structures have led a number of linguists to consider compound formation, especially formation of synthetic ones, ${ }^{2}$ as a matter of syntax (DI SCIULLO 2005, ANDERSON 1992, LIEBER 1992 among many others). For instance, ANDERSON (1992: 253-319) excludes compounding from his a-morphous morphology component. Similarly, ARONOFF (1994: 16) asserts that compounding should rather be treated as 'lexeme-internal syntax'. However, structures involving

\footnotetext{
${ }^{1}$ We would like to thank Carola Trips and Jaklin Kornfilt, the organizers of the 'Workshop on Phrasal Compounds from a Theoretical and Typological Perspective' (June 21, 2013, Mannheim, Germany) as well as Marios Andreou, Lieven Danckaert, Eric Lander and the audience of the workshop for their constructive remarks and help with the text. We are particularly grateful to Jaklin Kornfilt and Aslı Göksel for their elaborate comments and suggestions. Metin Bağrıç̧ı gratefully acknowledges the Research Foundation-Flanders (FWO13/ASP/010) for financial support for his research, and Angela Ralli the Research Funding Program THALIS, co-financed by the European Union (European Social Fund - ESF) and Greek national funds through the Operational Program "Education and Lifelong Learning" of the National Strategic Reference Framework (NSRF). The paper is the result of close collaboration and discussion by the two authors. However, for academic purposes, M.B. is mainly responsible for sections 3 and 4, A.R. for sections 2 and 5, while the remaining sections are the outcome of joint work.

${ }^{2}$ In synthetic compounds, "[...] the lexical head is derived from a verb. [...] The point about [synthetic compounds] is that the non-head of the compound seems to bear a syntactic dependency to the head, realizing its direct object or some other grammatical function." (Spencer 2005: 88).
} 
combinations of lexemes with morphological categories of an unclear status, socalled 'affixoids' (i.e. units which display properties of both stems and affixes), render difficult a radical separation of compounding and derivation: if derivation occurs in morphology, the presence of affixoids advocates a morphological status of compounding as well (see BOOIJ 2005 and RALLI 2010 for details).

SCALISE \& VOGEL (2010: 4-5) provide a survey of the different approaches that have been proposed in the literature with respect to compounding and conclude that there is no agreement among scholars on whether a compound is formed in morphology or syntax. It is worth mentioning their remark (2010: 2) that compounds constitute an 'anomaly' among grammatical constructions, since they behave like words but bear a type of 'internal syntax', which is usually manifested in the relation holding between their basic constituents, or in the theta-role saturation occurring within 'synthetic compounds'. In addition, the close relation between compounding and syntax is also revealed by the position of overtly realized inflection. Assuming that there is a distinction between inherent and contextual inflection, as proposed by BoOIJ $(1994,1996)$, and that only inherent inflection appears within word structure, ${ }^{3}$ compounding violates this rule in some languages. Typical examples can be found in Sanskrit and Ancient Greek, where a contextual case, such as accusative, can appear on the first constituent of compounds, i.e. compound-internally:

(1) a. Sanskrit [Bauer 2001: 703 (24a)]

dhana-m-jayá

wealth-ACC-winning

'winning wealth'

b. Ancient Greek [adapted from Ralli 2013a: 49] ${ }^{4}$

nou-n-ekhé:s

mind-ACC.SG-who.has

'prudent'

On the basis of the above observations, it is clear that attempts to define compounding and its locus in grammar encounter difficulties and the questions which arise can be resumed in two crucial points: what a compound is and where it is formed.

In this paper, we argue that the locus of compounding, whether it is in morphology or in syntax, is strictly compound-dependent. In other words, we argue that although compounding is ultimately a process of lexeme-formation, the output can be generated either morphologically or syntactically. This, however, does not mean that compound formation is exclusive to one and only one module in a given

3 "[i]t is only certain types of inherent inflection that can feed word formation." (Boolu 1994: 27).

${ }^{4}$ Throughout the paper, we will give detailed glosses for examples from Modern Greek (e.g. gender, number, case) only when they are directly relevant to the discussion. We choose to do so to avoid excessive morphemic information that might potentially render reading difficult. For a list of abbreviations employed, see section 'abbreviations' at the end of the current paper. 
language. On the contrary, as will become apparent throughout the paper, both morphologically and syntactically built compounds can occur in one particular language, as also shown by Ralli (2013b). If this proposal is on the right track, we should be able to see empirical correlations of such a dichotomy, both across two (or more) languages and within a single language, since otherwise we would have a redundant model with similar processes and constructions placed into separate components across and within languages. Our results show that such empirical correlations do in fact exist. To this end, we will first consider Modern Greek (henceforth MG) compounds, which, following RALLI (1992, 2005, 2007, 2013a,b), we will label as 'morphological items' and Turkish compounds, which following BAĞRIAÇIK \& RALLI (2013a) and RALLI (2013b), we will label as 'syntactic formations'. ${ }^{5}$ This study constitutes a ground where findings in two series of papers by us are compared to each other in a systematic manner. This comparison and our discussion of the locus of compounding bears significant implications on the non-homogenous group of phrasal compounds - compounds in which the non-head can host a phrase-level constituent (see LIEBER 1988, 1992: $11 \mathrm{ff}$ for earlier definitions). We will argue that the reason why MG does not allow phrasal elements inside its one-word compounds lies exactly in the fact that MG builds these structures morphologically. On the contrary, the fact that compounding can be syntactic in Turkish entails that this language can also have phrasal elements inside its compounds. Consequently, we will argue that languages in fact do not allow syntactic structures appearing in morphological ones. In that sense, the Lexical Integrity Hypothesis still holds. Lexeme-formation, on the other hand, takes place not only in morphology but in syntax as well, thus, opposing or defending the 'Lexical Integrity Hypothesis' becomes relevant only when a certain (group of) lexeme(s) are created in morphology/the lexicon. Lexemes which are syntactically built are irrelevant to the 'Lexical Integrity Hypothesis'. It should be acknowledged that our multi-component approach to different versions of essentially the same process is not entirely novel and it has also been formulated outside the realm of compounding, e.g. lexical versus syntactic passives (LAKS 2013), lexical versus syntactic reflexivization (REINHART \& SILONI 2005) or lexical versus syntactic reciprocalization (SILONI 2012).

The paper is organized as follows: In section 2, we will discuss compounding in $\mathrm{MG}, \mathrm{NN}$ and $\mathrm{AN}$ compounds in particular. We argue that these are morphological in nature. In section 3, we will discuss their Turkish equivalents, which we argue to be syntactic rather than morphological. In section 4, we turn to phrasal compounds in both languages and reveal that MG does not have compounds with clearly phrasal non-heads (which are longer than a lexeme or a word form, cf. the

\footnotetext{
${ }^{5}$ In BAĞRIAÇIK \& RALLI (2013), we discussed Turkish NN-sI concatenations (see section 3) as "Construct-State Nominals" versus "phrasal compounds", and argued that they follow distinct derivational routes. If this dichotomy we proposed in fact exists (but see criticisms to this approach in GÖKSEL (this issue)), in the light of the current paper, it should mean that the systematic differences between these two classes of nominal compounds have to be dealt with in syntax itself, and it does not mean that they are generated in distinct modules.
} 
definitions by MONTERMINI 2010, SCALISE \& VOGEL 2010), as a result of the fact that, in this language, compounding is a morphological phenomenon. In Turkish, on the other hand, nothing prevents the formation of phrasal compounds as compounding can also be syntactic in this language. ${ }^{6}$ Some restrictions in these compounds, as well as an analysis of these restrictions, are also presented in this section. In section 5, we will discuss a new set of data from MG, which can be considered phrasal compounds. This new set of data suggests that the locus of compounding should not be defined language-specifically, but compoundspecifically. Finally, section 6 concludes the paper.

\section{MG Compounds}

MG has rich and productive compounding, whereby two stems, i.e. units smaller than words (2a), or a stem and a word (3a) are concatenated with a compound marker - $o$ - interpolating in between the two. Lexemes created as the output of this process have idiosyncratic properties, such as unique stress, graphic unity, lexical integrity and so on, some of which are discussed in sections 2.1-2.5 (see RALLI 2013a: 13-25 for the full list of the criteria for MG 'compoundhood'). Compare the compounds in (2a), (3a) to $(2 b),(3 b)$, respectively, where the free, fully inflected word forms of the members of (2a),(3a) are given:

(2) a. trapez $_{[\text {[stem] }}-O-\quad$ mándil $l_{[\text {stem] }}-O$

table $\quad-$ CM- cloth $\quad$-NOM.SG

b. trapézi $\quad ; \quad$ mandíli

table.NOM.SG cloth.NOM.SG

(3) a. $\operatorname{mavr}_{[\mathrm{stem}]}-o-\operatorname{pinakas}_{[\mathrm{word}]}$

black -CM board.NOM.SG

'black board'

b. mávros 'black' ; pinakas 'board'

black.NOM.SG board.NOM.SG

NN (2a), AN (3a), AA (4a) AdvV (4b), NV (4c), VV (4d) are possible and productive combinations (the respective word forms of the compounds are given next to the examples, examples are taken from RALLI 2013a: appendix II):
(4) a. $m a k r_{[s t e m]}-o ́-\quad s t e n_{[s t e m]}-O S$
long -CM- narrow -NOM.SG
'long (and) narrow'
cf. makrís 'long' ; stenós 'narrow'
b. $k r i f_{[\mathrm{stem}]}-\mathrm{O}_{-} \quad$ tróyo $_{[\mathrm{word}]}$ secretly -CM- eat.1SG
cf. krifá 'secretly'; tróyo 'to eat'

\footnotetext{
${ }^{6}$ Yet, phrasal compounds only occur as a type of exclusively syntactic compound (see footnote 18).
} 

'eat secretly'
c. Aalas $_{[\mathrm{stem}]}{ }^{-O-} \quad$ pníyome $_{[\text {word] }}$
sea -CM- drown.1SG
'drown in the sea'
d. $\operatorname{ani}_{[\text {[stem] }}-O-$ klino $_{\text {[word] }}$ open -CM- close.1SG
cf. Aálasa 'sea' ; pníyome 'to drown'
cf. aníyo 'to open' ; klíno 'to close'

In the following sub-sections, we will show with a number of tests that MG compounds are one-word formations (for the tests in general see TEN HACKEN 1994), the structure of which cannot be affected by syntactic operations, such as binding, movement and ellipsis. Our arguments are mainly based on NN or AN compounds, but the argument developed in this paper carries over to other types of compounds as well.

\subsection{Word Atomicity}

When we consider 'word atomicity', MG compounds differ from their phrasal counterparts in six related respects:

Consider the AN compound in (5a) and its phrasal counterpart in (5b). First, compounds differ from their phrasal counterparts with respect to the fact that they do not allow insertion of another (functional or lexical) element within their structure (such as the adjectival stem mavr- of the word mávri 'black') (6a)), as opposed to their phrasal counterparts where this is possible (cf. the interpolated adjective mávri in (6b)):

(5) a. ayri-ó-yata wildcat (Felis silvestris)

(6) a. *ayri-o-mavr-ó-yata wild black cat int. 'wild-black-cat' b. áyria yáta wild cat

b. $i$ áfria mávri yáta the wild black cat 'the wild black cat'

Second, none of the constituents of a compound can be modified by, for instance, a degree modifier, which is in fact possible in the case of phrases ((7a) vs. (7b) respectively, see also (6a) and (6b)):
(7) a. *poli-ayri-ó-yata very wild cat int. 'very wildcat'
b. polí áyria yáta very wild cat 'very wild cat'

Third, no constituent in a compound can be coordinated ((8a) vs. (8b)) or elided ((9a) vs. (9b)):
(8) a. *ayri-o-ke-mejal-ó-yata
b. áyria ke mejáli játa 
wild and big cat

int.' wild- and big- cat' wild and big cat

'wild and big cat'

(9) a. ${ }^{*} o$ Marios iðe tin ayri-ó-yata ke o Yanis tin meyal-(ó)the Marios saw the wild-CM-cat and the Yanis the big-CM-

b. o Marios iðe tin áyria yáta ke o Yanis (iðe) tin meyáli the Marios saw the wild cat and the Yanis (saw) the big 'Marios saw the wild cat and Yannis (saw) the big (one)'

Fourth, no word-internal inflection can appear within compounds ((10a) vs. (10b)). In other words, the whole concatenation is inflected as one word (see also section 2.5):
(10) a. *ayri-es-ó-yat-es
wild-NOM.PL-CM-cat-NOM.PL
b. áyri-es yát-es
wild-NOM.PL cat-NOM.PL
'wild cats'

Fifth, no constituent in a MG compound can be wh-moved/wh-questioned (cf. BRESNAN \& MCHOMBO 1995) ((11a) vs. (11b)):
(11) a. *pjá $\mathrm{e}_{\mathrm{i}}$-ó-yata ine óyria? ${ }^{7}$ which -CM-cat is wild?
b. $p j a_{\mathrm{i}} \quad\left[\mathrm{DP}_{\mathrm{i}}\right.$ yáta $]$ ine áyria? which cat is wild?

Finally, pronominal reference (outbound anaphora, POSTAL 1969) to either of the constituents is ungrammatical ((12c) vs. (12d)), as (morphological) words seem to be anaphoric islands. Notice that in the compound (12c) the pronoun cannot take the non-head of the compound as its antecedent. The compound form and its phrasal counterpart in isolation are given in (12a) and (12b) respectively:
(12) a. arxond-ó-spit-o
cf. árxondas 'nobleman'; spíti 'house'
nobleman-CM-house-NOM.SG
'noble(man)-house'
b. spiti
árxonda
house.NOM.SG
nobleman.GEN.SG

\footnotetext{
${ }^{7}$ Note that the ungrammaticality of (11a) is not (morpho-)phonologically driven, although it is true that in a compound, the $\mathrm{CM}$ "[phonologically] appears on the first member of Greek compounds." (ANDREOU 2014: 49). The structure does not become grammatical even when a preceding eligible phonological host, albeit a fully inflected word and not a stem, is present (10a). This suggests that the ungrammaticality of (11a) is not due to the $\mathrm{CM}$ per se, but due to the fact that overall atomicity of the structure is violated. We thank Jaklin Kornfit for raising this issue.
} 
'nobleman's house'

c. *Pía sto arxond ${ }_{\mathrm{i}}$ óspito ke ton ${ }_{*} / \mathrm{j}$ iða

went.1SG to.the noble(man)house and him saw.1SG

him $\neq$ nobleman, him=somebody else

d. Píya sto spiti tu árxonda $\mathrm{i}_{\mathrm{i}}$ ke ton $_{\mathrm{i} / \mathrm{j}}$ iða

went.1SG to.the house the nobleman.GEN.SG and him saw.1SG

'I went to the nobleman's house and I saw him'

him=nobleman, him= somebody else

\subsection{Involvement of Functional Categories}

MG compounds display a semantically empty linking element between the first and the second constituents $(-o-)$, the presence of which is compulsory. RALLI (2008) defines it as a 'compound marker', that is, a functional element which marks the process of compounding. In other words, it is present exclusively in compound formations. As shown by ANASTASIADI-SYMEONIDI (1983), RALLI \& RAFTOPOULOU (1999) and RALLI (2007), -o- originates from an ancient thematic vowel, but became a compound marker already in the Hellenistic period (ca 3rd c. BC - 3rd c. AD) (see also NIKOLOU 2003, RALLI 2013a: section 2.3.4 for some phonologically conditioned irregularities concerning the CM, and RALLI 2013a: section 4 for some morphological irregularities):

(13) psar -o- tavérna

fish -CM- tavern

cf. psári ; tavérna

'fish tavern'

fish tavern

\subsection{Idiosyncratic Stress}

Beside their morphological properties, Greek compounds are also phonological words as they bear single stress, which, in many cases, falls on a different syllable from the stressed syllables of the two constituents in isolation ((14a) vs. (14b)) (see also NESPOR \& RALLI 1994, 1996 and RALLI 2013a: section 2.3.1 for details on the morphological conditioning of stress):
(14) a. ayri-ó-yata
wildcat
b. áyria yáta wild cat

Since the presence of single (main) stress accent characterizes wordhood in Greek (ARVANITI 2007: 130, and the references cited there; JOSEPH 2002: 256), this phonological property can be added to the morphological properties mentioned so far for determining the morphological status of MG compounds. 


\subsection{Bound Constituents}

The formation of Greek compounds usually involves stems, that is, parts of words without any inflectional ending. ${ }^{8}$ While the morphological category of the first constituent in a compound is always a stem, the category of the second constituent may be a stem or a word, depending on the compound. This has been formulated as the 'Bare-Stem Constraint' in RALLI \& KARASIMOS (2009). Example (15a) is a compound both members of which are stems since their inflectional endings are different from that of the second member when considered independently (15b). The compound in (16a) has a word as the right-hand constituent, as demonstrated by the identical inflectional ending of both the compound and the second constituent (cf. 16b) (see also (2)-(3) for more examples):

\section{(15) STEM+STEM}
a. anemóvroxo
b. ánemos ; vroxi wind-rain wind rain

(16) STEM+WORD
a. lemonantós
b. lemóni ; antós
lemon flower
lemon flower

\subsection{Inflection}

Related to the discussion in sections 2.1 and 2.4 is the fact that MG compounds are inflected as single stems. Compare, for instance, (17a) where a compound is inflected as one stem to (17b) where the respective phrase is case-marked both on the head and the non-head (MG DPs exhibit phi-feature agreement, i.e. agreement in terms of person, number, gender and case) between a head and (a) non-head(s)):
(17) a. tis
ayrióyata $-s$
b. tis áyria-s
yáta-s
of.the wildcat.FEM-GEN.SG ${ }^{9}$
of.the wild.FEM-GEN.SG cat.FEM-GEN.SG

In the case of the STEM+STEM type, the inflection of the whole concatenation is often different than that of the head in isolation (see section 2.4). Compare first the nominative inflection on the compound in (18a) to the nominative inflection on both the non-head and the head of the phrase in (18b):
(18) a. ayrioyúrun-o
b. áyri-o
yurúni-Ø
boar.NEUT-NOM.SG
wild.NEUT-NOM.SG pig.NEUT-NOM.SG

\footnotetext{
${ }^{8}$ In Modern Greek - as opposed to Ancient Greek - there is no synchronic difference between a root and a stem (RALLI 2005: 23, 2013a: 8). Hence, these two terms should be taken as synonyms as far as MG word formation is considered.

${ }^{9}$ According to RALLI (2002), gender is a lexically specified feature of stems while case and number belong to inflectional suffixes.
} 
And now compare the examples in $(18 \mathrm{a}, \mathrm{b})$ to the genitive case marked counterparts $(19 a, b)$ :
(19)a. $t u$
ayrioyúrun- $u$
b. $t u \quad a ́ g r i-u$
jurunj-ú
of.the boar.NEUT-GEN.SG
of.the wild.NEUT-GEN.SG pig.NEUT-NOM.SG

The tests applied so far to MG compounds can be summarized in the following table:

\begin{tabular}{lcc}
\hline Test & Compounds & Phrases \\
\hline \hline Insertion & - & + \\
\hline Independent Modification & - & + \\
\hline Coordination/ellipsis & - & + \\
\hline Internal inflection & - & + \\
\hline Wh-extraction & - & + \\
\hline Pronominal Reference & - & + \\
\hline Compound-specific marker & + & - \\
\hline Idiosyncratic Word-Stress & + & - \\
\hline Bound constituents & + & - \\
\hline External Inflection & + & - \\
\hline
\end{tabular}

Table 1. Properties of compounds and phrases in $M G$

Following RALLI (2013a,b), we interpret these discrepancies between the phrases and compounds as follows: compounding in $\mathrm{MG}$ is a process which is governed by properties different from those which characterize phrases. Therefore, it is safe to assume that MG compounds are morphologically built objects. Beside being subject to lexical integrity, they are single prosodic words and involve constituents that do not have a direct active role in the formation of phrases, i.e. stems, as well as a linking element $-o$ - which marks the process of compounding itself. In other words, the compounding mechanism produces stems (notated for ease as $\mathrm{X}^{-1}$ ), or full words $\left(\mathrm{X}^{0}\right)$.

\section{Turkish compounds}

Turkish NN concatenations with the $-(s) I(n)^{10}$ suffix at the right edge (henceforth NN-sI) (20a,b) have often been called 'possessive compounds' (SCHAAIK 1992, HAYASHI 1996, YÜKSEKER 1998) or simply 'compounds' (HANKAMER 1988, KORNFILT 1997a, GÖKSEL 2009). The suffix $-s I$ is called either a 'compound marker' (SCHAAIK 2002, KORNFILT 1997a) or 'linking element' (GÖKSEL 2008, 2009) and is generally said to have originated from a third person singular

${ }^{10}$ The phonemes inside parentheses surface in well defined phonological contexts. The phoneme in capital is an archiphoneme whose value is defined by vowel harmony. 
possessive agreement suffix (21) but to bear no meaning of possession in these concatenations (GÖKSEL \& KERSLAKE 2004: 104):

\section{(20) a. kapı kol -u door hand -sI 'door handle'}
b. çamaşır makina -sı laundry machine-sI 'washing machine'

\section{(21) Can -in araba-sl Can-GEN.3sg car-POSS.3SG \\ 'Can's car'}

Similar tests applied in section 2 to MG compounds reveal that their integrity differs only minimally from that of phrases.

\subsection{Word atomicity}

Turkish NN-SI compounds do not freely allow insertion of any other material in between the two constituents: the result of such interpolation is marginal at best. Compare (22a), in which the particle bile 'even' is inserted between the head and the non-head of the compound içişleri bakanı 'minister of internal affairs', to (22b) where a genitive-possessive phrase freely allows insertion of the same element:

\section{(22) a. ??*[[içişleri $] \quad$ bile bakan-l $] \quad$ ol-abil-ir- $\varnothing$ \\ 'internal.affairs even minister-sI be-ABIL-AOR-3SG}

int. 'He can be even the minister of internal affairs'
b. Buras
[[ayyaş-lar- $-\mathrm{ln}]$
bile $e v-i]$
$o l-d u-\varnothing$

Here.NOM drunkard-PL-GEN even home-POSS.3SG be-PAST-3SG

'Here, it became the house of even drunkards'

Second, contrary to phrases which freely allow modification of both the head and the non-head (23c), compounds allow only a modified non-head ((23a) vs. (23b)): ${ }^{11}$
(23) a. [beyaz zambak-lar] ülke-si white lilly-PL country-sI
'The country of white lilies'
b. gemi $[(*$ uzun $)$ dire $]$ ğ $i$ ship long pole-sI int.: 'long mast'

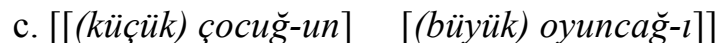 little kid-GEN.3SG big toy-POSS.3SG 'The big toy of the little kid'

Third, both constituents in an NN-sI compound can be coordinated, as illustrated by $(24 a)$ for the non-head, and by $(24 b, c)$ for the head:
(24) a. [yemek ve yatak] oda-si
b. ülke
[birlik ve beraberliğ ] $-i$

\footnotetext{
${ }^{11}$ Except for a few recent compounds where the head can be directly modified (GöKSEL \& KERSLAKE 2004: 99, ÖZSOY 2004).
} 
food and bed room-sI

'dining and bed room'

c. ülke [birliğ -i ve beraberliğ $-i]$

country unity-sI and solidarity-sI

'national unity and solidarity' country unity and solidarity-sI

'national unity and solidarity'

(24b)-(24c) illustrate the phenomenon of 'suspended affixation' (KORNFILT 1984, 2012 ) of $-S I$, i.e. the optional elision of $-S I$ in all conjuncts but the last one in a coordination structure. This is also observed in phrases:

(25) gösterici-ler-in yoğun çaba (-sl) ve ısrar-l demonstrator-PL-GEN.3SG vigorous effort(-POSS.3SG) and insistence-POSS.3SG 'The vigorous efforts and the insistence of the demonstrators'

If suspended affixation is a phenomenon operant on syntactic affixes, i.e. functional heads, as it has been argued by Kornfilt $(1998,2012)$ and as it is exemplified in (25), then according to us, the suspended affixation of $-s I$ constitutes evidence for the syntactic nature of the compounds (24b)-(24c) ${ }^{12}$ The possibility of chunking, a case of coordination without overt coordinator, in both constituent sites provides corroborative evidence for the fact that neither the head nor the non-head are atomic units:
(26) a. [televizyon, radyo, teyp, ü̈ü ] tamir-i TV radio tape.recorder iron repair-sI 'repair of TV, radio, tape recorder, iron'

b. otomobil [akü(-sü), şanzıman(-l), $\left.\operatorname{karoser}^{*}(-i)\right]$ car battery(-sI), gearbox(-sI), body-sI 'car battery, car gearbox, car body'

Fourth, only the (structural) non-head can be elided in Turkish compounds (27a). The ellipsis of the (structural) head yields to ungrammaticality (27b):

(27) a. ?Eda grev gözcü-sü ben ise sözcü-sü

Eda strike observer-sI I or spokesman-sI

'Eda is the picket and I am the spokesperson of the strike'

b. *Ali bir ders kitab-l al-dl-Ø, Veli de okuma Ali a lesson book-sI buy-PAST-3SG, Veli and reading int. 'Ali bought a textbook, and Veli a reading (book).'

\footnotetext{
${ }^{12}$ A comprehensive discussion of suspended affixation is beyond the scope of the current paper but the reader is referred to KORNFILT (1996); INKELAS \& ORGUN (1998); KABAK (2007); GöKSEL (2007:66-68) and KAHNEMUYIPOUR \& KORNFILT (2011) for certain conditions that suspended affixation is subject to.
} 
The ungrammaticality of (27b), according to us, does not indicate similarity of these constructions to morphological compounds (cf. (9a)) but should be explained by the fact that in Turkish (complex) NPs, there is a very strong ban against their lacking an overt head N, as shown KorNFILT (2005) with evidence from free relatives and by VON HEUSINGER \& KORNFILT (2005: especially section 4.2) with evidence from partitive constructions.

Fifth, there is at least contrastive evidence to MG compounds in that PL inflection can appear on non-heads in Turkish compounds ((28), see also (23a)):
(28) a. ögretmen-ler ev- $i$
teacher-PL house-sI
b. Şah-lar şah-l
'teacher's lodge'
Shah-PL shah-sI
'Shahanshah'

Sixth, the constituents in a compound can be wh-extracted: ${ }^{13}$
(29) a. $n e_{\mathrm{i}} \mathrm{e}_{\mathrm{i}}$ gazl kullan-mış-lar de-di-n?
what gas-sI use-EV-3PL say-PAST-2SG
'What (sort of) gas did you say that they used?

$$
\begin{gathered}
\text { a'. biber gaz-l } \\
\text { pepper gas-sI } \\
\text { 'pepper spray' }
\end{gathered}
$$

Seventh, pronominal reference to the non-head seems grammatical ((30a) which suggests that the non-head of the compound can bear some degree of referentiality; compound form is given in isolation in (30b) and the phrase is given in (30c):

(30) a. diş̧ ăgrt-sl durum-un-da $\emptyset_{\mathrm{i}}$ dolgu-sun-da bir sorun ol-abil-ir tooth ache -sI case-sI-LOC filling-sI-LOC a problem be-ABIL-AOR.3SG 'In case of toothache there might be a problem in its filling'
b. diş ăgrl-sl
tooth ache-sI
c. diş-in
dolgu-su
tooth-GEN.3sg filling-sI
'toothache'
'the filling of the tooth'

\subsection{Involvement of Functional Categories}

The $-s I$ suffix that occurs in an NN-sI compound has various functions (see GÖKSEL \& KERSLAKE 2004: 70 for a description), only one of which is marking a compound. As we have mentioned in section 3, the other relevant function of $-s I$ for the purposes of this paper is its function as a $3 \mathrm{rd}$ person possessive agreement marker in genitive-possessive constructions, as illustrated in (21). That these two functions are related has been subject to debate, especially when pairs such as those in (31a) are taken into consideration (cf. DEDE 1978: 50-59 for a discussion). It can occur only once in a concatenation, even in those cases where its presence (outside a compound) would otherwise be syntactically and semantically required.

\footnotetext{
${ }^{13}$ To be more exact, Turkish is a wh-in-situ language and thus there is no extraction of wh-words for that matter. Thus, the $e$ category in (29a) by no means implies a syntactic analysis and is used only for expository reasons.
} 
For example, consider the compound biber gaz-l (pepper gas-sI) 'pepper spray', which occurs in the head position of a genitive-possessive construction (31a). In this case, the co-occurrence of $-s I$ with the third person possessive agreement suffix results in ungrammaticality $(31 \mathrm{~b})$. This is valid for all person possessive agreement suffixes (LEWIS 1967, DEDE 1978, KORNFILT 1986, GÖKSEL 1988, 1993, SCHROEDER 1999, SCHAAIK 2002). That the possessive agreement suffix is actually required in a genitive-possessive construction is illustrated in $(31 \mathrm{c})$ where the head of the genitive-possessive construction is occupied by a non-compound: ${ }^{14}$

\author{
(31) a. polis-in biber gaz-l \\ police-GEN.3SG pepper gas-POSS.3SG \\ 'police's pepper spray'
b. *polis-in biber gaz-l-sl
police-GEN.3SG pepper gas-sI-POSS.3SG
c. polis-in müdahale-si
police-GEN.3SG intervention-POSS.3SG
'the intervention of the police'

The suffix $-s I$ has to occur last within the functional elements of a word, excluding the functional elements that link the word to higher structures, e.g. case. This property of $-s I$ has been noted to form bracketing paradoxes (GÖKSEL 1988, 1993). The plural form of NN-sI compounds are expected to display the sequence $s I+\mathrm{PL}$, whereas the grammatical form is PL $+-s I$ (cf. (32a) vs. (32b) respectively) $:^{15}$

$$
\begin{gathered}
\text { (32) a. *at araba-st-lar } \\
\text { horse coach-sI-PL }
\end{gathered}
$$

\section{b. at araba-lar-l \\ horse coach-PL-sI \\ 'hackney coach'}

Nor can -sI precede derivational suffixes, even though this might be the compositionally 'correct' position, hence the ordering of derivational suffixes and $s I$ is DER+-sI ((33b) vs. $(33 \mathrm{c})):^{16}$

\footnotetext{
${ }^{14}$ See HAIG (2004) as well, for an explanation in terms of 'morpheme-repetition-constraint'.

${ }^{15}$ The ill-formed versus grammatical sequences that we have mentioned here in $(32 a)$ and $(32 b)$ respectively, with respect to PL and $-S I$ in compounds, constitute only a subset of similar ordering constraints with respect to PL and AGR, observed most saliently in Turkish free relatives. Discussing this ordering constraint in Turkish free relatives is well beyond the scope of the current paper (see KORNFILT 1997b, 2005 and GÖKSEL 2007 for this constraint in free relative clauses). It should only be noted here that the $-s I$ in Turkish compounds behaves like its agreement counterpart, or any agreement morpheme-i.e. nominal agreement, in terms of ordering with respect to PL.

${ }^{16}$ See SchaAiK (2002: 84ff) who argues for the disjointness of the two structures in (33a) and (33b)). According to the author, the compound at araba-sl '(hackney) coach' in (33a) is not the input for the compound at araba-cl-sl 'coach rider' in (33b). In other words, (33b) does not derive from (33a), but $a r a b a-c l$ in (33b) derives prior to compounding from the lexeme araba 'coach'. The compound at $a r a b a-c l$ then is subject to a rule that dictates that such 'free terms' have to be marked with the compound marker -sI. Although this approach might at first glance seem more plausible, it falls short
} 
(33) a. at araba-s1 horse coach-sI '(hackney) coach'

c. *at araba-s1-c1 b. at araba-c1-s1 horse coach-DER-sI 'coach rider'

From the discussion above, it becomes clear that $-s I$ is a closing suffix (GÖKSEL 2009, GÖKSEL \& HAZNEDAR 2008:17ff). It can be followed only by case morphology, but not by other inflectional (32) or derivational morphology (33) - a peculiarity that it shares with other nominal agreement markers in Turkish (see footnote 15 for an exemplar case). This also means that contrary to the case of MG $\mathrm{CM},-s I$ is not only relevant to compounds but functions actively when the compound is connected to higher structures in syntax as well.

\subsection{Stress in Compounds}

The primary stress in NN-sI compounds falls on the stressable syllable of the nonhead, which is usually the final syllable of the first constituent (see GöKSEL 2009, GÜNEŞ 2009) (34). However, in genitive-possessive constructions as well, the primary stress falls on the ultimate syllable of the non-head (35):

\section{(34) Gemi halat-i ship rope-sI 'warp'}

\section{(35) polis-ín müdahale-sì} police-GEN.3SG intervention-POSS.3SG 'the intervention of the police'

Based on the phonological similarity between pairs such as (34)-(35), KAMALI \& İKIZOĞLU (to appear) argue that productive NN-sI compounds are syntactic and the stress pattern of these compounds is the expected stress pattern of a phrase.

\subsection{Free Constituents}

As should have become clear on the basis of the relevant examples given thus far, compounds in Turkish are built on words, i.e. on free items, not on stems.

\footnotetext{
of explanatory adequacy in cases where a compound with (a degree of) idiosyncratic meaning, such as (ia), enters into derivation, and where the idiosyncratic meaning of the input compound is retained in the derived compound (ib):

(i) a. ş1llık tatl1-s1 hussy dessert-sI

'a type of baklava-like dessert'

b. ş1llık tatl1-c1-s1 hussy dessert-DER-sI

'someone who sells the dessert in (ia)'
}

See HAYASH (1996) for a similar approach as we have developed here to the interaction of derivation and compounding. 


\subsection{Inflection}

In Turkish, there is evidence that inflectional elements occur within the structure of an NN-sI compound. Note that the PL suffix occurs to the left of the $-s I$ suffix (32b). In phrases as well, the PL marker precedes the possessive agreement suffix (36a). On the other hand, both case suffixes and clitics follow the $-s I$ in compounds and possessive agreement in genitive-possessive constructions ((36b) vs. (36c) respectively):

\section{(36) a. Can-ln akraba-lar-l}

Can-GEN.3SG relative-PL-POSS.3SG

'Can's relatives'

b. at araba-sin-da horse coach-SI-LOC 'in (the) hackney coach' c. Can-ln akraba-sin-dan

Can-GEN.3SG relative-POSS.3SG-ABL 'from Can's relative'

The results of the discussion so far can be summarized as follows:

\begin{tabular}{lll}
\hline Tests & Compounds & Phrases \\
\hline \hline Insertion & ??/* & + \\
\hline Independent Modification & + (non-head only) & + \\
\hline Coordination/ellipsis & + & + \\
\hline Internal inflection & $+/$ ? & + \\
\hline Wh-extraction & $+/$ (non-head only) & + \\
\hline Pronominal Reference & + & + \\
\hline Compound-specific marker & $-{ }^{17}$ & - \\
\hline Idiosyncratic Word-Stress & - & - \\
\hline Bound constituents & - & - \\
\hline External Inflection & + & + \\
\hline
\end{tabular}

Table 2. Properties of compounds and phrases in Turkish

As clear from the discussion and the table above, compounds in Turkish are to a large extent sensitive to syntax and its operations, although not quite as much as genuinely independent phrases (see especially examples in (27) and the discussion following the examples).

\subsection{Interim Results}

\footnotetext{
${ }^{17}$ It should be noted that the suffix $-s I$ in Turkish compounds has been glossed as CM by various authors (e.g. KORNFILT 1997, SCHAAIK 2002, RALLI 2008, GÖKSEL this issue) or as a linking element (GÖKSEL 2008, 2009). In this study, we do not want to take a stand on this terminological issue, thus this entry in the table only means that from a morpho-phonological point of view, there is no compound-specific marker in Turkish which has a synchronically different shape from another marker, i.e. 3rd person possessive.
} 
The results drawn from Turkish compounds in the preceding section clearly contrasts with those drawn from compounds in MG whose identity has been given in section 2 with identical tests:

\begin{tabular}{lll}
\hline Tests & $M G$ & Turkish \\
\hline \hline Insertion & - & $? ? / *$ \\
\hline Independent Modification & - & + (non-head only) \\
\hline Coordination/ellipsis & - & + \\
\hline Internal inflection & - & $+/ ?$ \\
\hline Wh-extraction & - & $+/$ (non-head only) \\
\hline Pronominal Reference & - & + \\
\hline Compound-specific marker & + & - \\
\hline Idiosyncratic Word-Stress & + & - \\
\hline Bound constituents & + & - \\
\hline External Inflection & + & + \\
\hline
\end{tabular}

Table 3. Comparison of compounds in $M G$ and Turkish

The interim result of the study are as follows:

MG clearly has compounds which are built in morphology, the items of which only morphology itself is responsible for. In contrast, we can legitimately claim that Turkish NN-sI compounds are made up of syntactic elements and are therefore built in syntax, despite the fact that there are certain differences between the respective derivations of compounds and phrases (see BAĞRIAÇIK \& RALLI 2013a for details). Turkish compounds are discussed as 'phrasal compounds' in BAĞRIAÇIK \& RALLI (2013a), and RALLI (2013b). ${ }^{18}$ It is important to note that being phrasal formations, Turkish compounds use a marker which can be characterized as a functional element employed in syntax. In this, they contrast with the morphologically built MG compounds, the specific marker of which originates from a purely morphological segment, the Ancient Greek thematic vowel -o-, which was nothing but a stem formative.

Our interim results provide supportive evidence for the 'Lexicalist approach' (LIEBER \& SCALISE 2006, BRESNAN \& MCHOMBO 1995: 181, ANDERSON 1992: 84, Di SCIUllo \& Williams 1987: 49, Botha 1984, SelKirk 1982: 70,

\footnotetext{
${ }^{18}$ This should not be taken as a robust generalization for 'all' types of compounding in Turkish: Apart from NN-sI compounds, Turkish also has bare compounds (those without $-s I$ suffix) as NN, AN, AA, NV, VV concatenations (see GöKSEL 2009: 214-216 for a neat list of these types). Discussing all these compound types and their locus of generation is beyond the scope of the current paper. It has been argued elsewhere (GöKSEL 2009, BAĞRIAÇIK \& RALLI 2013b) that the formation of these types is spread between the morphological module and the syntactic module, suggesting that in terms of their structure, the members of these compound sets stand on a continuum between being outputs of pure lexical derivation and of syntactic generation and semantic endocentricity/exocentricity does seem to play a crucial role in the syntactic transparency of these compounds. This means that in Turkish there are morphological compounds as well.
} 
LAPOINTE 1980: 8), but only on the condition that words-in our case compounds - are created in the morphological component of the grammar. ${ }^{19}$ The discussion so far, on the other hand, suggests that word formation may apply in syntax as well (see section 3), contrary to Bresnan's argument that word formation is exclusively a morphological process and that syntactic rules have no access to internal word structure and hence cannot create words (BRESNAN 1997, 2001):

\footnotetext{
${ }^{19}$ Aslı Göksel points out that an assumption about the Lexical Integrity Hypothesis (LIH) that applies only to morphological mechanisms (but not to syntactic ones) seems to make the LIH unfalsifiable, and she asks what a possible example of a LIH violation would be. According to this line of thinking, an example such as

(i) on-suz-luk

him/her-PRV-ness

'the state of being without him/her'
}

would not violate LIH because it would be considered a syntactic formation, whereas the ungrammaticality of

(ii) *on-lu-luk

him/her-REL-ness

'int: the state of being with him/her'

would support the LIH because a word is an anaphoric island (according to Bresnan \& Mchombo 1995).

According to us, if the $\mathrm{LIH}$ is violable without yielding ungrammaticality, then the structure is not a morphological one. In that sense, the hypothesis is teleological, it is a test for the locus of a certain structure. In Turkish, both the privative and the relational suffixes are phrasal suffixes (cf. BAĞRIAÇIK \& RALLI 2013a) given that both can select phrases:
(iii) $[\mathrm{kar}$$$
\text { dağın }
$$
ardındaki
kasaba]-11,
opposite mountain.GEN beyond.POSS.LOC.RTV town -REL
'someone from the town beyond the opposite mountain'

Yet, they have to attach to the head of the phrase (cf. Input Correspondence, ACKEMA \& NEELEMAN 2004: 164). Therefore, according to us, the ungrammaticality of (ii) does not mean that $-l I$ is a lexical suffix and hence the ill-formedness is due to words' being anaphoric islands. First, note that examples such as Ahmet Hakan-lı bir haber programı 'a news program with Ahmet Hakan' or Cem Adrian-ll bir toplant ' 'a meeting with Cem Adrian' where - $I I$ attaches to referential elements are grammatical although further affixation of the derivatinal suffix $-l I K$ makes the structures ungrammatical, i.e. *Ahmet Hakan-ll-llk 'int.: the state of being with Ahmet Hakan'. This is not unexpected since suffixes may be subject to combinatorial ordering restrictions (cf. GöKSEL 2007). Second, the relational -lI suffix is subject to more selectional constraints: kimse-siz 'without anyone' is grammatical whereas *kimse-li is ill-formed, although kimse 'anyone' is not a referential element. Thus, the ungrammaticality of *on-lu, according to us, is due to a competition between itself and the commitative -(y)lA: on-la/on-un-la 'with him', kimse-yle 'with anyone' are perfectly grammatical. Such suppletive forms in a paradigm are everywhere in natural languages, although at this moment and in our case we are not sure what causes the suppletion.

Note that even if our argument is on the wrong track, we should still clarify that even the seemingly same suffix might attach syntactically and morphologically, but only in the first one is it not subject to the LIH, e.g. - $m A$ in Modern Turkish (KoRNFILT 2012: 188-189). 
"Morphologically complete words are leaves of the c-structure [syntactic, M.B. \& A.R.] tree and each leaf corresponds to one and only one c-structure node."

(Bresnan 2001: 92)

The 'relaxation' that we have proposed with respect to mechanisms of compound-formation, and ultimately to the Lexical Integrity Hypothesis (in its many different guises) leads to the following hypothesis: Since MG has only morphological compounds where only elements of morphology are involved, phrasal compounds, i.e. compounds where the non-head is a phrase-level constituent, should not be able to occur in this language. On the other hand, in Turkish where compounding can also be syntactic and - at least- the non-head is phrasal, nothing should preclude the productive occurrence of phrasal constituents in the non-head position. In the next section, we will test this hypothesis.

\section{Phrasal Compounds in MG and Turkish}

Germanic languages have been reported to productively generate phrasal compounds where the non-head is a phrasal projection (TRIPS 2012, MEIBAUER 2007, Lieber \& SCALISE 2006, SCALISE \& GuEVARA 2005, ACKEMA \& NEELEMAN 2004, BoOIJ 2002, WIESE 1996, LIEBER 1992 to name a few, examples in (37) are from MEIBAUER 2007: 235-6): ${ }^{20}$

(37) a. [lach of ik schiet] humor laugh or I shoot humor (Dutch)

b. der [Vater-und-Sohn] Konflikt the father and son conflict (German)

c. an [ate-too-much $]$ headache

d. [God is dod] theologie God is dead theology (Afrikaans)

MG, in contrast, does not allow phrase-level projections in the non-head position, contrary to Germanic languages. Compare the ungrammatical $(38 \mathrm{a}, \mathrm{c}, \mathrm{e})$, where the non-heads are phrasal, with the NN compounds in $(38 \mathrm{~b}, \mathrm{~d}, \mathrm{f})$ :
(38)a. *[ср mi ríxnete
skupiðja]-(o) ${ }^{21}$-simo not throw.2PL garbage-CM-sign int.: 'do-not-litter' sign'
b. oð-ó-simo road-CM-sign 'signpost'

\footnotetext{
${ }^{20}$ For a categorization of phrasal compounds in English see TRIPS (2012) and in German MEIBAUER (2007).

${ }^{21}$ The overt occurrence of the CM in these examples or lack thereof is not related to the ill-formedness of the examples in (38), (40) for reasons that become clear in the text below.
} 
c. *[pp me tin próti matjá]-(o)-érotas with the first sight -CM-love int.: 'love at first sight'

e. *[DP i néa kúkla]-(ó)-spito the new doll-CM-house int.: 'new-doll house' d. jerond-o-érotas old.man-CM-love

'love at old age'

f. kukl-ó-spito

doll-CM-house

'doll house'

That MG does not allow phrasal non-heads, on the one hand, provides evidence for the Lexicalist approach, and on the other provides counter-evidence to approaches to phrasal compounds which involve (almost limitless) interaction between morphology and syntax. For example, in ACKEMA \& NEELEMAN's approach (2004), syntactic constituents can be inserted into a morphological unit as long as feature matching takes place between the inserted maximal projection and the non-maximal projection into which the relevant element is inserted. However, as is clearly shown above in (38), MG does not allow this type of 'Generalized Insertion'. To our knowledge, MG is not the sole language of this type; as far as compounding, and the appearance of a phrase-level constituent inside a compound is considered, Armenian and Slavic languages behave similar to MG. Given this idea, it is in fact not clear why phrasal constituents cannot be inserted into the nonhead position, as opposed to, say, their Germanic counterparts. One might argue that feature matching does not take place between the insertee $\mathrm{X}$ and the inserted $X P$, yet ACKEMA \& NEELEMAN do not provide an account for what these features can be. Following MEIBAUER's reasoning, one can argue that the related feature is [+/-nominal], and that MG phrases do not qualify as [+nominal]. However, see (38e) where the non-head clearly bears the [+nominal] feature. Besides, MG has $\mathrm{CP}-$ level nominalizations where a $\mathrm{CP}$, selected by an overt functional nominal element, D, becomes a DP (39b) (for further details of nominalization see BORSLEY \& KORNFILT 2000, KORNFILT \& WHITMAN 2011) and can occur in case positions $(39 \mathrm{c}, \mathrm{d})$ :

\section{(39) a. éfije} $\mathrm{s} /$ he left

c. [to óti éfiye] apoðikníi tin enoxí tis the that left.3SG show.3SG the guilt her 'that s/he left proves his/her guilt'

d. đen amfisvitó [to óti éfiye] not dispute. $1 \mathrm{SG}$ the that left. $3 \mathrm{SG}$ 'I do not dispute the fact that s/he left' b. to óti éfiye the that $\mathrm{s} /$ he.left 'that $\mathrm{s} /$ he left'

(Roussou 1991:87 [=25a])

(BORSLEY \& KORNFILT 2000:114 [=56]) 
Returning to the issue of MG compounds, even these nominalized CPs, which are DPs and clearly [+nominal], cannot be inserted into the non-head position:

(40) *[to óti éfiye $]-(o)$-jeyonós

the that $\mathrm{s}$ /he left-CM-fact

int: 'that-(s)he-left-fact'

Why they cannot appear in the non-head position neatly follows from the discussion in section 2. MG compounds are purely morphological, whereby the left-hand constituent is always a stem $\left(\mathrm{X}^{-1}\right)$, never a phrase-level projection (XP). Therefore regardless of the exact nature of the phrase to be inserted in the non-head position, no phrase-level constituent can function as a stem.

Based on this fact, we argue that 'Generalized Insertion' cannot be generalized to languages where compounding is without a doubt morphological and involves only morphological units.

Turkish, on the other hand, allows larger phrases in the non-head position, i.e. as noun complements (see SCHAAIK 2002 who discusses them as 'higher-order compounds'):

$$
\begin{aligned}
& \text { [polis-in orantısız güç kullan-diğ-l] haber-i } \\
& \text { police-GEN disproportionate force use-FNOM-3SG news-sI } \\
& \text { 'the news that the police used disproportionate force' }
\end{aligned}
$$

In the example above (41), the whole TP is nominalized (KORNFILT \& WHITMAN 2011: 1302) by the Factive Nominalizer (FNOM), as also indicated by the 3rd singular agreement suffix. The subject is in genitive case which is assigned by the head of the nominalizing functional projection. ${ }^{22}$

That DPs and any D-related projection, e.g. NumP, are allowed even in non-head position in Turkish is witnessed by the following example where the non-head is a Numeral phrase in (42):

(42) iki adam boy-u two man length-sI 'the height of two men'

The elements that make use of the D-projection of the noun phrase have been claimed to be excluded in compounds (DI SCIULlO \& WILLIAMS 1987: 50; ${ }^{23}$

\footnotetext{
${ }^{22}$ In earlier work, the nominalizing functional projection is claimed to be an AgrNP (BORSLEY \& KorNFILT 2000, KORNFILT 2003) and in recent work a DP, (KoRNFILT \& WhitMAN 2011), but nothing hinges on this. Genitive subjects are licenced by movement to Spec,DP via Spec,TP.

${ }^{23}$ Di ScIUllo \& WilliaM's original argument (1987: 50) is primarily based on proper names and pronouns - more specifically inbound anaphora, according to which a word cannot contain pronouns that are referential. According to them, famous proper names constitute an exception to this, but in such cases the names are not referential. General objections to the restriction both on inbound anaphora and on the occurrence of proper names have been put forward by HARRIS (2006). Since we
} 
PosTAL 1969), yet the Turkish data do not obey this generalization (42). Note that these constructions are not allowed in MG (see also the ungrammatical (38e)):

(43) *[tria peðj(a)]-o-latría three children-CM-love int: 'love for three children'

as opposed to

\section{(44) peð-o-latría \\ child-CM-love \\ 'love for children'}

If there are syntactic compounds in Turkish, then nothing should preclude the involvement of another syntactic unit in these compounds; in this case a DP which is the nominalized phrasal projection of a TP (41), since the verbal terminus, TP, and the functional projections below become irrelevant to further syntactic operations. In other words, contrary to what would follow from ACKEMA \& NEELEMAN (2004), in Turkish, there is no morphological compound in which a syntactic unit is inserted. Rather the entire compound formation takes place in syntax, and the non-head is perfectly eligible for phrasal projections, a DP projection being only one of the possibilities.

Additional evidence for the irrelevance of the terminal projection of the nonhead, and the functional projections below it when it enters a compound formation, comes from examples in (45), where finite IPs/CPs occur in the non-head position:

(45) a. [polis orantısız güç kullan-dl-Ø] haber-i police disproportionate force use-PAST-3SG news-sI 'the news that the police used disproportionate force'

b. [polis orantısız güç kullan-dl-Ø mı?] soru-su police disproportionate force use-PAST-3SG Q question-sI "the question "did the police use disproportionate force"

c. [dayan Gezi] slogan-l

resist.IMP Gezi (Park) slogan-sI

'the slogan 'Resist Gezi (Park)'

(45) shows that there are also non-nominal phrases (e.g. IPs/CPs) which can occur as non-heads. Note that this constitutes another problem for ACKEMA \& NEELEMAN's argument about 'Generalized Insertion': We have seen in MG compounds that even though feature matching might occur, phrasal elements are

are not sure at the moment about the properties of proper names, we refrain from incorporating them into our discussion. 
still excluded from the non-head position in this language. In (45), we see that even though it is inconceivable what features are common to the terminal node of the compound structure and the inserted phrase (CP/IP), these phrases can still occupy the non-head position of Turkish compounds. ${ }^{24}$

So far, we have shown that MG does not but Turkish does have "phrasal compounds' where the non-head position is occupied by a phrase-level projection. The ungrammaticality of such phrasal compounds in MG follows from the fact that compounding in MG is solely a morphological process that requires - at leastnon-heads to invariably be stems. On the contrary, Turkish allows phrase-level projections in the non-head position, arguably because (apart from morphological compounds (see footnote 18)) there are compounds as outputs of a syntactic wordformation process in Turkish. So far, we have not come across formations where syntactic constituents occur inside morphologically built constituents. Therefore, the Lexical Integrity hypothesis, according to us, still holds, though one should be careful in which language and on which type of concatenations the hypothesis is tested.

\section{Phrasal Compounds in MG}

Does the whole discussion in section 4 mean that MG cannot have phrasal compounds at its disposal in any process of word formation?

Our answer to this question is negative. MG does in fact have two (innovative) types of concatenations where the constituents are not stems but fully inflected words. These types are quite recent formations (observed only in the last two centuries), are almost always confined to specific jargon, and have most probably emerged under the influence of French and English (RALLI 2013a). The types involve AN and NN-GEN concatenations (46a, 46b respectively): ${ }^{25}$

\footnotetext{
${ }^{24}$ According to GöKSEL (this issue), NN-sI compounds with phrasal non-heads fall into two distinct categories, citational compounds and quotational compounds and she shows that there are certain structural differences between the two. She interprets this dichotomy as follows: only citational compounds are syntactically transparent and are 'phrasal compounds'. They can be of categories CP, IP, DP/NP and N. Quotational compounds on the other hand are syntactically opaque, and are compounds where there is an 'IS A' relationship between the non-head and the head. They can be only Ns, but without having the syntax corresponding to Ns. Although her argument about the need for bifurcation is very well supported by empirical evidence, her approach faces the same problem present in ACKEMA \& NEELEMAN's approach: it is not entirely clear how to deal with the structural placement of a quotation within a compound.

${ }^{25}$ There is another small group of non-homogenous concatenations, namely NN ones with two inflected words:

(i) léksi kliði

word.NOM.SG key.NOM.SG

'key word'
}

The members of this category do not behave uniformly with respect to further inflection and insertion. RALLI (2013a: 255) calls them phrasal-compound-like phrases and claims that "[...] they are under the process of desyntacticisation, in the sense that they are progressively passing from a full syntactic status to that of phrasal compounds". The reader is referred to RALLI (2013a) for a detailed account of these concatenations. 
(46) a. AN

Jimósi-os ipálil-os cf. English civil servant

public.MASC-NOM.SG servant.MASC-NOM.SG

'civil servant'

b. NN-GEN

$\begin{array}{ll}\text { zóni } & \text { asfalia-s } \\ \text { belt.FEM.NOM.SG } & \text { safety.FE }\end{array}$

cf. French ceinture de sécurité

belt.FEM.NOM.SG safety.FEM-GEN.SG

'safety belt'

They are termed as 'phrasal compounds' (RALLI 2013a) or 'loose multi-word compounds' (RALli 2005, 2007; KOLIOPOULOU 2013) and exhibit hybrid properties: on the one hand, unlike phrases, they share with compounds (cf. section 2 ) the properties of not allowing D-elements (47), not allowing insertion of other constituents (48), not allowing focalization (49) and not allowing scrambling (50):

(47) a. *o đimósios o ipálilos the public the servant

(48) a. *o đimósios, kalós, ipálilos the public, good, servant b. *izóni tis asfalía-s the belt the.GEN safety-GEN

b. *i zóni meyáli-s asfalía-s the belt big-GEN safety-GEN

(49) a. *To đimósio iða ton ipálilo the.ACC civil.ACC saw.1SG the.ACC servant.ACC int.: 'It was the civil servant that I saw'

b. * ti zóni éðese asfalía-s the.ACC belt.ACC fastened. 3SG security-GEN int.: 'It was the safety belt that s/he fastened'

(50) a.*o ipálilos o dimósios the servant the public

b. *asfalia-s $i$ zóni safety-GEN the belt.NOM

On the other hand, similar to noun phrases, they are composed of fully inflected words with case and number (46). Moreover, they are two distinct prosodic domains with distinct stress assignment (51):
(51) a. Jimósi-os ipálil-os public servant 'civil servant'
b. zóni asfalía-s belt safety-GEN 'safety belt'

More importantly, however, these two categories behave like phrases when further inflection is involved. In the AN type, PL is realized on both the non-head 
and the head (52a), which is reminiscent of the requirements of phi-feature agreement in DPs (52b), while in NN-GEN types, the plural PL is realized only on the head (52c). Compare (52c) to (52d), where the corresponding genitive phrase bears PL marking on the head:

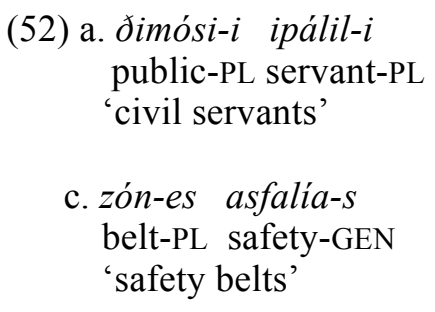
c. zón-es asfalía-s
belt-PL safety-GEN
'safety belts'
b. mávr-i skíl-i
black-PL dog-PL
'black dogs'
d. ta peðj-á tis jitonjá-s
the child-PL the.GEN neighborhood-GEN
'the children of the neighborhood'

Finally, although very marginally, there is some rare evidence suggesting that these items could be subject to further compounding of the same type. Consider the AN structure in (53a) and the NN-GEN one in (53b):
(53) a. steyn-ó kaӨárizma
dry cleaning
'dry cleaning'
b. fak-ós epafi-s
lens contact-GEN
'contact lens'

In (54), the formations in (53a) and (53b) constitute the heads of the further NNGEN concatenations ((54a)-(54b) respectively). Notice that in (54b), the GEN suffix is attached to the head of the compound fakós epafis 'contact lens':

$$
\begin{aligned}
& \text { (54) a. ??[[steynó kaAárizma] asfalía-s] } \\
& \text { dry cleaning safety-GEN } \\
& \text { 'dry cleaning with care' } \\
& \text { b. [iyró [fak-ón epafi-s]] } \\
& \text { liquid lens-GEN.PL contact-GEN } \\
& \text { 'contact lens solution' }
\end{aligned}
$$

The examples (47)-(50) and (51)-(54) show that the AN and NN-GEN formations show structural similarities to both morphological compounds and syntactic phrases, but diverge radically from the morphological compounds, presented in section 2. Further research is clearly required for the exact status of these new categories, but their resemblance to phrases and difference from morphological compounds strongly suggests that they have a phrasal status, as stated in RALLI (2013a). In this paper, we follow RALLI's (2013a) suggestion that they constitute phrasal compounds.

Notice that when AN phrasal compounds are subject to further derivation, which is a morphological process and hence requires stems as inputs, the phrasal 
compounds in (55) are stripped of their inflectional endings, and are, thus, restructured into compound stems, that is, into morphological items $(56):{ }^{26}$

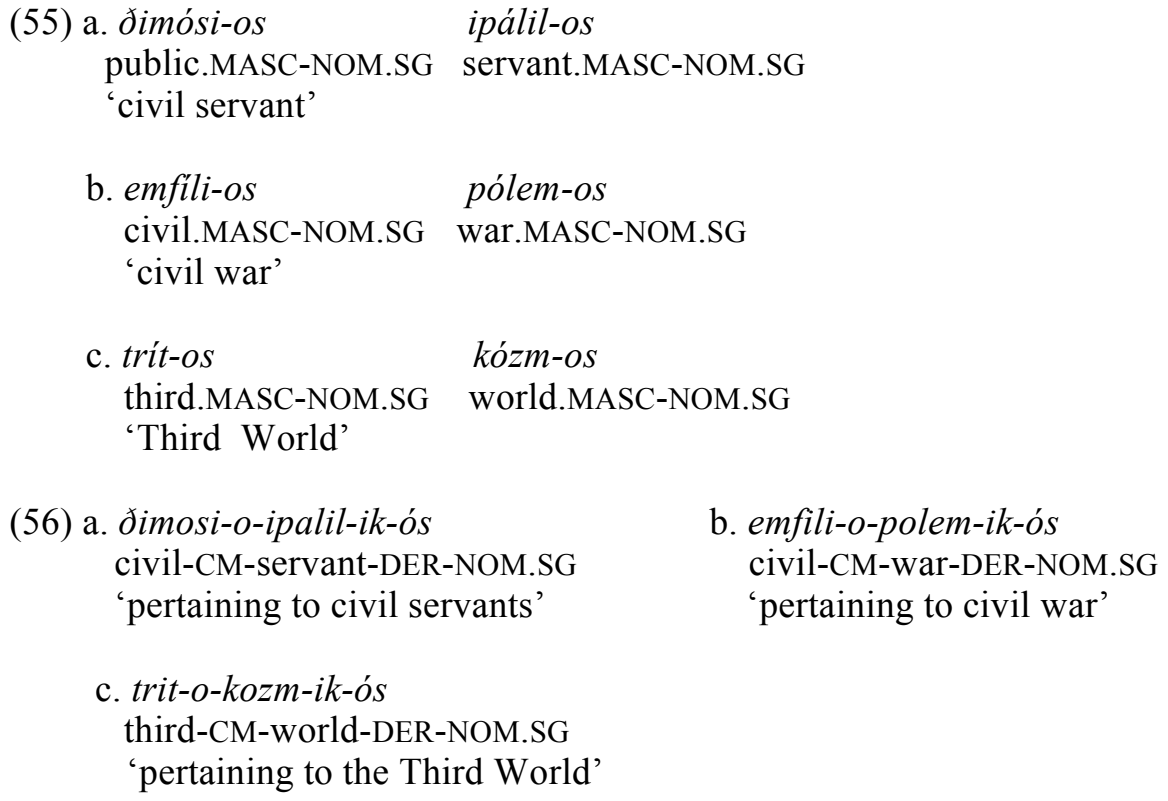

As foreseeable, the restructured phrasal compounds (55), which can constitute input for a morphological process such as derivation (provided that they are stripped of their inflectional endings (56)), can also become input for morphological compounding of the type that has been discussed in detail in section 2, as (57) clearly shows:

(57) a. meyal-o-ðimosi-o-ipólil-os

big-CM-civil-CM-servant-NOM.SG

'big civil servant'

b. emfili-o-polem-o-xar-ís

civil-CM-war-CM-satisfied-NOM.SG

'someone who likes civil war(s)'

c. trit-o-kozm-o-fovía

third-CM-world-CM-fear.NOM.SG

'fear from the Third World'

This is an expected outcome, given that inflection follows both derivation and morphological compounding.

\footnotetext{
${ }^{26}$ Note that NN-GEN compounds cannot enter into such derivational processes, probably because the internal inflection that should be stripped belongs to the head (see Ralli 2013a for further details).
} 


\section{Conclusions}

In this study, we have looked at MG NN and AN compounds with the compound marker $-o$ - and Turkish NN-sI compounds. We have shown that while MG compounds are morphological and hence show no degree of transparency to syntactic operations, Turkish compounds are syntactic and hence reveal a high degree of transparency to syntactic operations. This result has two certain interrelated implications for the 'Lexical Integrity Hypothesis', namely: (a) word formation, which also involves compounds with phrasal non-heads, is not confined to morphology (or the lexicon) but can take place in syntax as well; (b), as a result of (a), the Lexical Integrity Hypothesis should be maintained only for items which are morphologically created, as suggested earlier by KORNFILT \&WHITMAN (2011) and in the work on which KORNFILT \&WHITMAN's approach is based (see the original work for references).

The fact that compounds can be formed both as morphological and syntactic objects also reveals why certain languages display the so-called 'phrasal compounds' but others do not. We have demonstrated that MG is of the latter type, in that this language allows only for purely morphological constituents in the formation of compounds with the compound marker. As a result, syntactic phrases, regardless of their features, are not allowed inside MG compounds. On the other hand, Turkish freely tolerates the appearance of both non-finite and finite IPs/CPs, as well as DPs (and D-related projections), in the non-head position. The fact that these maximal projections can occur as non-heads in NN-sI compounds stems from the fact that compounding in Turkish can also be syntactic and can hence involve functional heads and projections.

Finally we have looked at a small, non-homogenous class of compounds in MG, which have been developed analogically to compounds in English and French. We suggested that, given their similarity to phrases, they also bear a 'phrasal status', following a previous proposal put forward by Ralli (2013a), albeit in a different fashion than phrasal compounds in Turkish. The overall findings suggest that the locus of compounding should not only be defined language-specifically. Rather, it might be the case that, even within a language, two constructions that can both be $a$ priori called 'compounds' can be generated in different modules of the grammar.

\author{
Abbreviations \\ $\mathrm{ABIL}=$ ability \\ $\mathrm{ACC}=$ accusative \\ $\mathrm{AGR}=$ agreement \\ $\mathrm{AOR}=$ aorist \\ $\mathrm{CM}=$ compound marker \\ $\mathrm{DER}=$ derivational suffix \\ $\mathrm{EV}=$ evidential \\ $\mathrm{FEM}=$ feminine \\ $\mathrm{FNOM}=$ factive nominalizer \\ GEN $=$ genitive \\ $\mathrm{IMP}=$ imperative
}

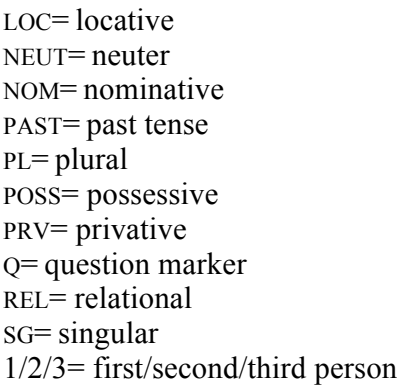




\section{References}

Ackema, Peter \& Neeleman, Ad (2004): Beyond morphology: Interface conditions on word formation. Oxford: Oxford University Press.

ANASTASIADI-SYMEONIDI, ANNA (1983): La composition en grec moderne d'un point de vue diachronique, in: Lalies 2, 77-90.

ANDERSOn, STEPHEn R. (1992): A-Morphous morphology. Cambridge: Cambridge University Press. ANDREOU, MARIOS (2014): Headedness in word formation and Lexical Semantics: Evidence from Italiot and Cypriot, $\mathrm{PhD}$ dissertation. University of Patras, Greece.

ARONOFF, MARK (1994): Morphology by itself: Stems and inflectional classes. Cambridge, MA: MIT Press.

Arvaniti, Amalia (2007): Greek phonetics. The state of the art, in: Journal of Greek Linguistics 8, 97-208.

BAĞRIAÇIK, METIN \& RALLI, ANGELA (2013a): NN-sI concatenations in Turkish: Construct-state nominals and phrasal compounds, in: OzGE, UMUT (ed.), Proceedings of the 8th workshop on Altaic formal linguistics, MIT Working Papers in Linguistics \#67. Cambridge, MA: MIT Press, $13-24$.

BAĞRIAÇIK, METIN \& RALLI, ANGELA (2013b): Bare N(ominal) N(ominal) concatenations in Turkish: Compounds or syntactic fallacies?, in: HATHOUt, NABIL; MonTERmini, FABIO \& TSENG, JESSE (eds.), Morphology in Toulouse. Selected proceedings of Décembrettes 7, Toulouse, 2-3 December 2010. Munich: Lincom Academic Publishers, 35-56.

BAuer, LAURie (2001): Compounding, in: HaSPelmath, MARTin; KÖNIG, EKKeHARD; OESTERREICHER, WULF \& RAIBLE, WOLFGANG (eds.), Language universals and language typology, vol.1. Berlin \& NY: de Gruyter, 695-707.

BOOIJ, GEERT (2005): Compounding and derivation: Evidence for Construction Morphology, in: Dressler, Wolfgang; Rainer, Franz; Kastovsky, Dieter \& Pfeiffer, Oskar (eds.), Morphology and its demarcations. Amsterdam / Philadelphia: John Benjamins, 109-132.

BOOIJ, GEERT (2002): The morphology of Dutch. Oxford: Oxford University Press.

BOOIJ, GEERT (1996): Inherent versus contextual inflection and the split morphology hypothesis, in BOOIJ, GeERT \& VAN MARLE, JAAP (eds.), Yearbook of Morphology 1993. Dordrecht: Kluwer, 116.

BoOIJ, GeERT (1994): Against split morphology, in: BoOIJ, GeERT \& VAN MARLE, JAAP (eds.), Yearbook of Morphology 1993. Dordrecht: Kluwer, 27-50.

BORSLEY, ROBERT \& KORNFILT, JAKLIN (2000): Mixed extended projections, in: BORSLEY, ROBERT (ed.), The Nature and function of syntactic categories (Syntax and semantics, volume 32). San Diego, CA: Academic Press, 101-131.

BOTHA, RUDOLPH P. (1984): Morphological mechanisms. Lexicalist analyses of synthetic compounding. Oxford: Pergamon Press.

BRESNAN, JOAN (2001): Lexical-functional syntax. Malden, MA: Blackwell.

BRESNAN, JOAN (1997): Mixed categories as head sharing constructions, in: BUTT, MIRIAM \& Holloway KInG, Tracy (eds.), Proceedings of the LFG97 conference. Stanford: CSLI, available at http://www.stanford.edu/group/cslipublications/cslipublications/LFG/2/bresnan-lfg97.pdf.

BRESNAN, JoAN \& MCHOMBO, SAMUEL A. (1995): The lexical integrity principle: Evidence from Bantu, in: Natural Language \& Linguistic Theory 13, 181-254.

DEDE, MüŞERREF A. (1978): A syntactic and semantic analysis of Turkish nominal compounds. $\mathrm{PhD}$ dissertation, University of Michigan.

DiScIUllo, ANNA MARIA (2005): Asymmetry in morphology. Cambridge, MA: MIT Press.

DiSciullo, ANNA MARIA \& Williams, EDWIN (1987): On the definition of word. Cambridge, MA: MIT Press.

GÖKSEL, ASLI (2009): Compounds in Turkish, in: Lingue e Linguaggio 8 (2), 213-36.

GÖKSEL, ASLI (2008): Linkers on the edge: Turkish compound marking. Paper presented at the CompNet Congress on Compounding, 6-7 June 2008, University of Bologna, Italy.

GÖKSEL, ASLI (2007): Morphology and syntax inside the word: Pronominal participles of headless relative clauses in Turkish, in: BoOIJ, GEERT; DUCCESCHINI, LuCA; FrADIN, BERnARD; GueVARA, Emiliano; Ralli, Angela \& SCAlise, Sergio (eds.), Online proceedings of the fifth 
Mediterranean morphology meeting, Frejus, 15-18 September 2005, 47-72. Available at http://morbo.lingue.unibo.it/mmm/mmm-proc/MMM5/MMM5-Proceedings_full.pdf.

GÖKSEL, ASLI (1993): Levels of representation and argument structure in Turkish. $\mathrm{PhD}$ dissertation, SOAS, University of London.

GöKSEL, ASLI (1988): Bracketing paradoxes in Turkish nominal compounds, in: KoÇ, SABRI (ed.), Studies on Turkish linguistics. Ankara: METU Press, 287-298.

GöKSEL, ASLI \& HAZNEDAR, Belma (2008): Remarks on compounding in Turkish. Ms. Boğaziçi University. Available at http://componet.sslmit.unibo.it/download/remarks/TR.pdf.

GöKSEL, ASli \& KeRSlaKe, Celia (2004): Turkish. A comprehensive grammar. London: Routledge.

GüNEŞ, GÜLiz (2009): On the formation of $[V+V]$ compounds in Turkish. Paper presented at the 2nd Mediterranean graduate students meeting in linguistics, 12-13 March, 2009. Mersin, Turkey.

HAIG, GeOFFREY (2004): Constraints on morpheme repetition in Turkish?, in: IMER, KAMILE. \& DOgAn, GuRKAN (eds.), Current research in Turkish linguistics. Gazimagusa: Eastern Mediterranean University Press, 3-12.

HANKAMER, JORGE (1988): Parsing nominal compounds in Turkish, morphology as a computational problem, in: Occasional Papers 7. LA: University of California at LA.

HARRIS, AlicE C. (2006): Revisiting anaphoric islands, in: Language 82 (1), 114-130.

HAYASHI, TORU (1996): The dual status of possessive compounds in Modern Turkish, in: BERTA, ÁrPÁd; Brendemoen, BernT \& SchönIG, Claus (eds.), Symbolae Turcologicae. Studies in honor of Lars Johanson on the occasion of his sixtieth birthday, 6. İstanbul: Swedish research institute in Istanbul, Transaction, 119-29.

INKELAS, SHARON \& ORGUN, ORHAN (1998): Level (non)ordering in recursive morphology: Evidence from Turkish, in: Lapointe, SteVen G.; Brentari, Diane K.; \& FARRell, Patrick M. (eds.), Morphology and its relation to phonology and syntax. Stanford: CSLI Publications, 360-410.

Joseph, BRIAn D. (2002): The word in Modern Greek, in: Dixon, ROBERT M. W \& AiHKENVALD, AleXANDRA Y. (eds.), Word. A cross-linguistic typology. NY: Cambridge University Press, 243265.

KABAK, BARIŞ (2007): Turkish suspended affixation, in: Linguistics 45 (2), 311-347.

KAHNEMUYIPOUR, ARSALAN \& KORNFILT, JAKLIN (2011): The syntax and prosody of Turkish 'prestressing' suffixes, in: Folli, RAFFAELla \& UlBRich, Christiane (eds.), Interfaces in linguistics: New research perspectives. Oxford: Oxford University Press, 205-221.

KAMALI, Beste \& İKizoĞLu, Didem (to appear): Against compound stress in Turkish, in: Proceedings of the 16th international conference on Turkish linguistics.

Koliopoulou, MARIA (2013): Themata synthesis tis ellinikis ke tis germanikis: Sigkritiki prosengisi [Issues of Modern Greek and German compounding : A contrastive approach]. $\mathrm{PhD}$ dissertation. University of Patras. Patras, Greece.

KORNFILT, JAKLIN (2012): Revisiting 'suspended affixation' and other coordinate mysteries, in: Brugé, Laura; Cardinaletti, Anna; Giusti, Giuliana; Munaro, Nicola \& Poletto, Cecilia (eds.), Functional heads: The cartography of syntactic structures, Volume 7. NY: Oxford University Press, 181-196.

KORNFILT, JAKLIN (2005): Free relatives as light-headed relatives in Turkish, in: BROEKHUIS, HANS; CORVER, Norbert; Huybregts, Riny; KleinHEnz, Ursula \& Koster, JAN (eds.), Organizing grammar: Studies in honor of Henk van Riemsdijk (volume 86 of Studies in Generative Grammar). Berlin \& NY: de Gruyter, 340-349.

KORNFILT, JAKLIN (2003): Subject case in nominalized clauses, in: JunGHANNS, UwE \& SzUCSICH, LUKA (eds.), Syntactic structures and morphological information. Berlin \&NY: de Gruyter, 129215.

KORNFILT, JAKLIN (1997a): Turkish. London: Routledge.

KORNFILT, JAKLIN (1997b): On some constraints governing free relative clauses in Turkish, in: İMER, Kamile \& Uzun, N. Engin (eds.), Proceedings of the VIIIth international conference on Turkish linguistics. Ankara: Ankara Üniversitesi Basımevi, 17-24.

KorNFILT, JAKLIN (1996): On Copular clitic forms in Turkish, in: AlEXIADOU, ARTEMIS; FuHrhop, NANNA; LAW, PAUl \& LÖHKEN, SYLVIA (eds.), ZAS Papers in Linguistics 6. Berlin: ZAS, 96-114. 
KORNFILT, JAKLIN (1986): The Stuttering prohibition and morpheme deletion in Turkish, in: AKSUKoç, Ayhan \& Erguvanli-Taylan, Eser (eds.), Proceedings of the second international conference in Turkish linguistics. Istanbul: Boğaziçi University Publications, 59-83.

KORNFILT, JAKLIN (1984): Case marking, agreement, and empty categories in Turkish. $\mathrm{PhD}$ dissertation. Harvard University. Cambridge, MA.

KORNFILT, JAKLIN \& WHITMAN, JOHN (2011): Afterword: Nominalizations in syntactic theory, in: Lingua 121, 1297-1313.

LAKS, LIOR (2013): Passive formation in Palestinian and Standard Arabic: Lexical vs. syntactic operations, in: Word Structure 6, 156-180.

LAPOINTE, Steven G. (1980): The theory of grammatical agreement, PhD dissertation. University of Massachusetts, Amherst.

LEWIS, GEOFFREY L. (1967): Turkish grammar. Oxford: Clarendon Press.

LIEBER, ROCHELLE (1992): Deconstructing morphology: Word formation in syntactic theory. Chicago \& London: Chicago University Press.

LIEBER, ROCHELLE (1988): Phrasal compounds in English and the morphology-syntax interface, in: Brentari, Diane; Larson, Gary \& Macleod, Lynn (eds.), CLS 24: Papers from the 24th regional meeting of the Chicago Linguistics Society, part two: Parasession on agreement in grammatical theory. Chicago: Chicago Linguistic Society, 398-405.

Lieber, Rochelle \& SCALiSe, Sergio (2006): The Lexical Integrity Hypothesis in a new theoretical universe, in: Lingue e Linguaggio 5, 7-32.

MEIBAUER, JÖRG (2007): How marginal are phrasal compounds? Generalized insertion, expressivity, and I/Q-interaction, in: Morphology 17, 233-259.

Montermini, FABio (2010): Units in compounding, in: SCALiSe, Sergio \& Vogel, Irene (eds.), Cross-disciplinary issues in compounding. Amsterdam: John Benjamins, 77-92.

NesPor, Marina \& RALli, Angela (1996): Morphology-Phonology interface: Phonological domains in Greek compounds, in: The Linguistic Review 13, 357-382.

Nespor, MARina \& RALli, Angela (1994): Stress domains in Greek compounds: A case of morphology-phonology interaction, in: PHILIPPAKI-WARBURTON, IRENE; NICOLAIDIS, KATERINA \& SifIANOU, MARIA (eds.), Themes in Greek linguistics. Papers from the 1st international conference on Greek linguistics, Amsterdam \& Philadelphia: John Benjamins, 201-208.

NiKOLOU, KALOMOIRA (2003): Morfologiki ke fonologiki analysi ton monolektikon sintheton tis Ellinikis [Morphological and phonological analysis of Greek one-word compounds]. MA Thesis. University of Aegean, Rhodes, Greece.

ÖZsOY, SUMRU (2004): Dışișleri eski bakanı ve Türkçe'nin yeni yapısı, in: TosKa ZEHRA (ed.), Kaf Dăğ 'nın ötesine varmak, Günay Kut Armăganı, Vol. 3, Journal of Turkish Studies, Türklük Bilgisi Araştırmaları 28 (1). Harvard University, 247-256.

Postal, Paul M. (1969): Anaphoric islands, in: Chicago Linguistic Society 5, 209-239.

RAlli, Angela (2013a): Compounding in Modern Greek. Dordrecht: Springer.

RALLi, ANGela (2013b): Compounding and its locus of realization: Evidence from Greek and Turkish, in: Word Structure 6, 181-200.

Ralli, Angela (2010): Compounding versus derivation, in: Scalise, Sergio \& Vogel, Irene (eds.), Cross disciplinary issues in compounding. Amsterdam: John Benjamins, 57-76.

RALLI, ANGELA (2008): Compound markers and parametric variation, in: Language Typology and Universals (STUF) 61, 19-38.

RALLI, ANGELA (2007): I sinthesi lekseon: Diaglossiki morfologiki prosengisi [The composition of words: A cross-linguistic morphological approach]. Athens: Patakis.

Ralli, Angela (2005): Morfologia [Morphology]. Athens: Patakis.

RALLi, ANgela (2002): The Role of morphology in gender determination: Evidence from Modern Greek, in: Linguistics 40 (3), 519-551.

Ralli, Angela (1992): Compounds in Modern Greek, in: Rivista di Linguistica 4 (2), 143-173.

RALLI, ANGELA \& KARASIMOS, ATHANASIOS (2009): The bare-stem constraint in Greek compound formation, in: Gengo Kenkyu 135: 29-48.

RALLI, ANGELA \& RAFTOPOULOU, MARIA (1999): I sinthesi os diachroniko fenomeno schimatizmu lekseon [Compounding as a diachronic word-formation process], in: Studies in Greek Language 1998. Thessaloniki: Kyriakides, 389-403. 
REINHART, TANYA \& SILONI, TAL (2005): The Lexicon-Syntax parameter: Reflexivization and other arity operations, in: Linguistic Inquiry 36, 389-436.

Roussou, ANNA (1991): Nominalized clauses in the syntax of Modern Greek, in: UCL Working Papers in Linguistics 3, 77-100.

Scalise, Sergio \& Guevara, Emiliano (2005): The Lexicalist Approach to word-formation and the notion of the lexicon, in: ŠTEKAUER, PAVOL \& LIEBER, ROCHELle (eds.), Handbook of wordformation. Dordrecht: Kluwer, 147-187.

Scalise, Sergio \& Vogel, Irene (2010): Why compounding?, in: Scalise, Sergio \& Vogel, Irene (eds.), Cross disciplinary issues in compounding. Amsterdam: John Benjamins, 1-18.

SCHAAIK, GERJAN VAN (2002): The Noun in Turkish: Its argument structure and the compounding straitjacket. Turcologica 49. Wiesbaden: Harrassowitz Verlag.

SCHAAIK, GERJAN VAN (1992): The treatment of Turkish nominal compounds in FG, in: FORTESCUE, MiCHAEL; HARDER, PETER \& KRISTOFFERSEN, LARS (eds.), Layered structure and reference in a functional perspective. Amsterdam: John Benjamins, 231-252.

SCHROEDER, CHRISTOPH (1999): The Turkish nominal phrase in spoken discourse. Wiesbaden: Harrassowitz Verlag.

SELKIRK, ElisabeTH O. (1982): The syntax of words, Cambridge, MA: MIT Press.

SILONI, TAL (2012): Reciprocal verbs and symmetry, in: Natural Language and Linguistic Theory 30, 261-320.

SPENCER, ANDREW (2005): Word formation and syntax, in: ŠTEKAUER, PAVOL \& Rochelle, Lieber (eds.), Handbook of word-formation. Dordrecht: Springer, 73-97.

TEN HACKEN, PIUS (1994): Defining morphology: A principled approach to determining the boundaries of compounding, derivation, and inflection. Hildesheim: Olms.

TRIPS, CAROLA (2012): The interpretation of phrasal compounds in the model of Parallel Architecture, in: Ralli, Angela; Booij, Geert; Scalise, Sergio \& Karasimos, Athanasios (eds.), Morphology and the architecture of grammar: Online proceedings of the 8th Mediterranean Morphology Meeting, 14-17 September, 2011, Cagliari, Italy, 322-346. Available at http://lmgd.philology.upatras.gr/en/research/downloads/MMM8_Proceedings.pdf.

VON HEUSINGER, KLAUS \& KORNFILT, JAKLIN (2005): The case of the direct object in Turkish: Semantics, syntax and morphology, in: Turkic Languages 9, 3-44.

WiESE, RichARD (1996): Phrasal compounds and the Theory of Word Syntax, in: Linguistic Inquiry 27, 183-193.

YÜKSEKER, HitAY (1998): Possessive constructions in Turkish, in: JOHANSON, LARS (ed.), in cooperation with Csató, Eva ÁGNes; Locke, VANESSA; MENZ, Astrid \& WinTERLING, DorotheA, The Mainz meeting. Proceedings of the VIIth international conference of Turkish linguistics (Turcologica 32). Wiesbaden: Harrassowitz Verlag, 458-477.

\section{Correspondence addresses}

Metin Băgrıaçık

Department of Linguistics

Ghent University

Blandijnberg 2, 9000

Ghent, Belgium

Metin.bagriacik@UGent.be

Angela Ralli

Department of Philology

University of Patras,

Rio, 26504

Patras, Greece

ralli@upatras.gr 